\title{
The Impact of Socially Responsible Reporting on Successful Corporate Operations
}

\author{
Anton Peršić ${ }^{1}$, Mirko Markič ${ }^{2}$ \\ ${ }^{1}$ Sallaumines 10a, 1420 Trbovlje, Slovenija, anton.persic@triglav.si \\ ${ }^{2}$ University of Primorska, Faculty of Management, Cankarjeva 5, 6000 Koper, Slovenia, mirko.markic@fm-kp.si
}

\begin{abstract}
The aim of our research was to study the impact and purpose of the reporting on socially responsible conduct on the success of corporate operations. The data and information were gathered with the quantitative research method, whereas the instrument for gathering them was a questionnaire that was distributed among 759 large and medium sized organisations from the field of market services in the Republic of Slovenia. We have established that activities aimed at socially responsible conduct are directly connected with the success of corporate operations, especially the revenue $(p=0.001)$, the profit of a company $(p=0.000)$, operational growth $(p=0.007)$ and operational economy $(p=0.002)$, and are typical for organizations with a larger number of employees $(p=0.032)$. In this regard, the real estate and construction market activities received the lowest scores. Research results provide theoretical as well as practical benefits for everyone dealing with the planning, implementation and control of sustainable development, as well as socially responsible conduct within the organization.
\end{abstract}

Key words: sustainable development, social responsibility, market services, operational success

\section{Introduction}

Socially responsible conduct by organizations is in favour of the society, and can be the foundation of a long-term development and growth of said organization. With the questionnaire directed at the members of top management of organizations from the field of market services we wanted to study the expectations and objectives of reporting on social responsibility, and their impact on improving operational results. According to historical data, every society fails when social responsibility as the crucial element of ethical attitude disappears since it prevents narrow-minded and short-lived selfishness (Mulej and Hrast, 2012). The paradigm of social responsibility in general is gaining popularity within the global social environment (Avolio and Gardner, 2005). The focus is shifting towards the organisation's management in the field of employee motivation and constant adaptation to market demands (McAlister et al., 2005; Amabile and Kramer, 2007, 72-83; Daft, 2010; Yukl, 2010), towards new technological advancements, innovativeness, sustainable development of the organization (Becker et al., 2003; Wilson, 2010), and generally towards the knowledge management of the employees in the organization (Hron, 2004; Ortenblad, 2004; Nohria et al., 2008; Dimovski et al.,
2010). Also the demands and expectations of consumers keep changing. They require from the employees in those organizations to constantly adapt to the social environment, they demand an approach to the operational development as well as the creation of added value that is more and more innovative (Schwarz and Carroll, 2003; Kaplan and Norton, 2006; Jeston and Nelis, 2008; Markič et al., 2012).

In the current economic situation in the European Union, it is being explicitly emphasized that socially responsible conduct by organizations is no longer a lonesome or self-sufficient initiative to change the business environment. It is much more the most suitable tool for resolving critical socially-economic issues in the society (Mulej and Hrast, 2012). The principles and guidelines of social responsibility are outlined in the most recent release of the ISO 26000 standard, which links the principles of management with the business excellence model EFQM (Green paper, 2010; ISO 26000, 2010). The latter is especially important in the service industry since services are provided by suitably qualified and motivated employees. That is why mutual trust, personal and business reputation, as well as ethical operations of an organization and its employees are the basic conditions that need to be fulfilled in order to assure a successful cooperation with the consumers in the long-term (Windsor, 2006; Celinšek and Markič, 2008). 
In all developed economies, services in general represent the biggest and growing economic sector from the viewpoint of employment, social capital, and added value. That is why the competitiveness of services is the key determining factor of growth and welfare in modern economies. Besides, services that are directly linked to products or production also play an important role in assuring the competitiveness of the industrial sector. The employment potential of the service sector has been changing significantly over last 50 years. According to Eurostat data for 2011 the employment share in the service sector in Slovenia is $67.26 \%$, whereas the average number in the EU member states is as high as $76.98 \%$ (in 2008, the average was $75.79 \%$ ) - the number is highest in the most well developed EU member states. A very important role of social capital in the global economy plays the field of "market services" as defined by Panorama of European Business. For EU member states, the share of "market services" in the total capital raised in 2011 was $48.09 \%$, whereas it was $43.45 \%$ for Slovenia, which means an increase from $42.29 \%$ in comparison with the year of 2008 (Eurostat, 2012).

Successful organizations propel the development of business excellence and social responsibility models for a comprehensive improvement of the competitiveness of a state. The EFQM business excellence model can serve as an example of integration and as a system for the improvement of an organization's operational success on the basis of the integration of models and leadership standards (Singhal and Hendricks, 2004; Bukovec and Markič, 2008). Numerous studies worldwide and in Slovenia confirm that the connection between social responsibility and economic success has been identified (Kern Pipan, 2010). Therefore Bakker et al. states that 127 empirical studies were reviewed in 2003. Mostly, they confirmed the positive link between individual key components of social responsibility and a financial success of an organization (Bakker, 2008). There have also been international studies on the meaning of social responsibility and its impact on the operational success of companies conducted. They included organizations from the Republic of Slovenia (KPMG, 2005; KPMG, 2008) that in the first place pointed out very limited awareness and generally gravely insufficient reporting on the crucial meaning of social responsibility principles and their consideration in their business environment. What is more, organizations merely acknowledged socially responsible conduct as highly limited forms of sponsorships and donations to non-governmental organizations and associations. They were mostly unfamiliar with environmental aspects, sustainable development, excellence, and the improvement of operations. Also Bodlaj in his research statistically proves the direct connection between market focus of an organization in the social environment, innovations, and business excellence. Integrated standards of managing an organization have been established as the starting point of this link (Bodlaj, 2009).

In Slovenia, a formal quality and excellence strategy until 2015 has already been developed (SFBE, 2011). Also a national strategy of social responsibility according to the international standard ISO 26000 has been elaborated as an upgrade of excellence models, which significantly supports the resolution of the global social and economic crisis under the current circumstances. But as a matter of fact, no real effect has been observed in business practices, especially in the field of understanding the meaning and benefits of sustainable reporting on socially responsible conduct, whereas this is the most evident in the service sector (Fink Babič and Biloslavo, 2012). The latter can even be the key to economic development and the growth of the entire society, especially under these critical economic circumstances. Innovations and a revamp of business processes, suitable motivation of employees, constant improvement of competencies of managers and the whole workforce, development and research, as well as creating a higher added value in the operations of an organization are inevitable in order to enable a long-term development and growth of the organization (Kottler and Lee, 2004; Verle et al., 2012).

In the context of the research, we created the following hypothesis H1: "Reporting on the social responsibility to external stakeholders is more characteristic of organizations with successful operations." With the hypothesis, we want to assess the impact of socially responsible reporting on operational success. Therefore the purpose of this article is to research the impact and the actual meaning of reporting on socially responsible conduct on operational success of medium sized and large organizations from the market services sector in the Republic of Slovenia.

\section{Methodology}

The quantitative research method, as described by EasterbySmith, Thorpe and Jackson (2008), served as the foundation for the drafting of the questionnaire. Based on the findings of pilot testing performed in August 2012, we prepared the final version of the questionnaire, which comprised 11 groups of questions. All the selected variables within individual groups measure the field in question or its dimension. In order to prepare the content of the questionnaire, we used some of the existing measurement instruments from previous research, i.e. the questionnaire at the Horus award (Mulej and Hrast, 2012) on the influence of constant improvements and human capital (Kern Pipan, 2010), correlation between social responsibility and financial success of organizations (Gray and Milne, 2004; Porter et al., 2006; Bakker, 2008; Margolis and Elfeibein, 2008), as well as the meaning of social responsibility in Slovenian organizations (KPMG, 2008; CSR, 2009; KPMG, 2011; Fink Babič and Biloslavo, 2012). For the evaluation of questions, we used the 5-grade Likert scale for comparing individual results of the research with previous studies, and their effective processing with the SPSS software.

Within the poll that was carried out in September 2012, we distributed the questionnaire among 759 organizations registered in the "market services" sector. The questionnaire was usually addressed to senior executives (members of the management board, executive officers) as the representatives of top management, who also carry the greatest responsibility for taking the principles of social responsibility into consideration, and for the operational success of their organization. The purpose of the questionnaire was to obtain a written assessment of the impact of internal and external aspects of social responsibility - in the forms of activities and report- 
ing. At the end of the poll, the data were exported from the "FluidSurveys.si" environment and imported into the SPSS software suite. All gathered primary data were statistically analysed using suitable descriptive and inferential statistics. We used a normality test (the Kolmogorov-Smirnov Test and the Shapiro-Wilk Test) to examine the distribution of the gathered data and determine the statistical characteristic in most cases (one-way t test). With the Spearman's rank correlation coefficient, we examined the connection between the aspects of activities and reporting on socially responsible conduct within the organization and in the social environment. Whereas with the independent samples nonparametric test (Kruskal-Wallis), we examined the existence of characteristic differences with regard to the activity sector, size, productivity, efficiency, and ownership of the organization.

According to the official data of the Agency of the Republic of Slovenia for Public Legal Records and Related Services (AJPES), there were altogether 759 registered companies under the "market services" designation (according to the Standard Industrial Classification of the Republic of Slovenia 2008 under the codes D through N) in the Republic of Slovenia on 31 March 2012 - 635 medium sized (50-249 employees) and 124 large (more than 250 employees). When sampling the organizations for the study we took the actually crucial impact of market services or services as sources of income provided by medium sized and large companies on the social product creation, their immediate influence on socially responsible conduct, and their fundamental focus on the expertise and certification of quality standards as well as the EFQM business excellence model. There are virtually no micro or small organizations in the field of "market services" (with less than 50 employees) whose conduct and reporting on socially responsible conduct would have a significant impact, or that have obtained quality certificates or other excellence models in Slovenia. They also do not boast of Awards of the Republic of Slovenia for Business Excellence. By sampling the organizations in the study that way, we could more reliably confirm the importance of factors of socially responsible conduct and reporting thereof on management systems in the field of market services that have the strongest impact on the social environment.

\section{Results}

136 participants across all fields of "market services" activities in the Republic of Slovenia filled out the entire questionnaire. The highest number (19 each) were executives from the fields of commerce, banking and insurance, as well as various other fields of economic activity (14\% of all participants each). 41 questionnaires $(31.2 \%)$ were filled out by representatives of large organizations (more than 250 employees), 67.7\% participants were members of top management, $69.1 \%$ participants had at least a bachelor's degree or an equal level of tertiary education. The average age was 44 years and the average years of employment in the company they run was 14 years. The number of participants (136) out of total 759 invited organizations means a $17.9 \%$ participation share, which is acceptable for the integrity of the statistical analysis of data from this research. The structure of the participating organizations in $\%$ by field of activity is shown in Table 1 .

Table 1: Share of Organizations Participating in the Researchby Field of Activity

\begin{tabular}{|l|c|}
\hline Field of activity & $\begin{array}{c}\text { Share } \\
\text { \% }\end{array}$ \\
\hline Commerce (G) & 14.0 \\
\hline Finance and insurance (K) & 14.0 \\
\hline Other various business activities (N) & 14.0 \\
\hline Transport and storage (H) & 10.3 \\
\hline $\begin{array}{l}\text { Professional, scientific and technical } \\
\text { activities (M) }\end{array}$ & 10.3 \\
\hline Electricity, gas and steam supply (D) & 8.1 \\
\hline Water supply, sewage treatment (E) & 8.1 \\
\hline Construction (F) & 8.1 \\
\hline Hospitality (I) & 6.6 \\
\hline $\begin{array}{l}\text { Information technology and } \\
\text { communication (J) }\end{array}$ & 3.7 \\
\hline Real estate (L) & 2.2 \\
\hline No response & 0.7 \\
\hline
\end{tabular}

Social responsibility activities are usually conducted by the employees in an organization. They are directed towards a comprehensive environmental protection (waste sorting, energy efficiency), providing a safe and healthy work environment, respecting values and codes of conduct, efficient communication on all management levels, team work, and generally improving operating results and the development of the organization. The results of the research on the reporting about social responsibility in the form of activities are shown in Table 2.

With the one-way t test, we have confirmed that a large majority of companies execute all activities that are bound to external reporting. The only parameter with an above average rating is the sponsorship of events taking place in the local environment ( $p=0.410)$. With the Spearman's rank correlation coefficient, we established how the reporting on social responsibility by means of activities of the employees in an organization is connected with the characteristics of the companies - with the revenue $(p=0.001)$, profit $(p=0.001)$, operational growth $(\mathrm{p}=0.007)$, number of employees $(\mathrm{p}=0.032)$, and the economy of a company $(p=0.002)$. We wanted to know if various activities from the field of socially responsible conduct executed in large "market services" companies impact the operation, revenue, profit, operational growth, economy, and productivity, which was demonstrated with the Spearman's rank correlation coefficient in Table 3.

The forms of reporting on socially responsible conduct have already been established in mostly large organizations from the sector of "market services". How they might be linked to the operational success, the field of activity, and the ownership of the organization is shown in Table 4.

With regard to the one-way t test we can confirm the statistically characteristic above average reporting on social 
Table 2: Descriptive statistics - reporting in the form of activities

\begin{tabular}{|c|c|c|c|c|c|}
\hline REPORTING in the form of activities & $\mathbf{N}$ & $\mathbf{M}$ & Me & Mo & $\begin{array}{l}\text { St. } \\
\text { Dev. }\end{array}$ \\
\hline $\begin{array}{l}\text { Our company promotes waste sorting, electricity and heating energy efficiency, } \\
\text { as well as water conservation }\end{array}$ & 136 & 4.6 & 5.0 & 5 & 0.627 \\
\hline $\begin{array}{l}\text { Preventive activities in the field of occupational health and safety are a part of } \\
\text { all operational processes. }\end{array}$ & 136 & 4.1 & 4.0 & 4 & 0.820 \\
\hline $\begin{array}{l}\text { In our organization, we regularly analyse processes and products/services in } \\
\text { order to keep improving the organization, as well as its success and performance. }\end{array}$ & 136 & 4.1 & 4.0 & 5 & 0.872 \\
\hline $\begin{array}{l}\text { Our company encourages its employees to participate in team work and to strive } \\
\text { for open communication by giving them an opportunity to participate in vari- } \\
\text { ous sports, leisure and entertainment activities in a broader social environment } \\
\text { (cycling, trekking, entertainment events). }\end{array}$ & 136 & 4.1 & 4.0 & 4 & 0.953 \\
\hline $\begin{array}{l}\text { In our company, we acknowledge the understanding of and the commitment to } \\
\text { values, culture, and the code of socially responsible conduct of all employees. }\end{array}$ & 136 & 4.0 & 4.0 & 4 & 0.834 \\
\hline $\begin{array}{l}\text { As a rule, our company introduces environmentally friendly technologies into } \\
\text { its products/services. }\end{array}$ & 136 & 4.0 & 4.0 & 4 & 0.834 \\
\hline $\begin{array}{l}\text { Our company encourages its employees to strengthen multiculturalism and } \\
\text { tolerance towards others also by encouraging them to participate in charity } \\
\text { activities and philanthropy in a broader social environment (blood donation, } \\
\text { assistance to elderly citizens). }\end{array}$ & 136 & 3.7 & 4.0 & 3 & 1.04 \\
\hline $\begin{array}{l}\text { Our company regularly takes part in environmental cleanups and landscaping } \\
\text { activities in a broader social environment. }\end{array}$ & 136 & 3.6 & 4.0 & $4 \mathrm{a}$ & 1.16 \\
\hline $\begin{array}{l}\text { Our company provides regular donations to organizations that dedicate them- } \\
\text { selves to helping children and adolescents (e.g. organizing seaside vacations, } \\
\text { events for children, setting up recreational surfaces). }\end{array}$ & 136 & 3.5 & 3.0 & 3 & 0.981 \\
\hline $\begin{array}{l}\text { Our company encourages its employees to participate in various cultural events } \\
\text { in their local environment. }\end{array}$ & 136 & 3.4 & 3.0 & 3 & 1.05 \\
\hline $\begin{array}{l}\text { Our company provides regular sponsorships to professional and scientific con- } \\
\text { ventions from our field of operation. }\end{array}$ & 136 & 3.3 & 3.0 & 3 & 1.10 \\
\hline $\begin{array}{l}\text { Our company provides regular sponsorships to sports clubs and events taking } \\
\text { place in our local environment. }\end{array}$ & 136 & 3.2 & 3.0 & 3 & 1.09 \\
\hline $\begin{array}{l}\text { Our company provides regular sponsorships to entertainment and cultural events } \\
\text { taking place in our local environment. }\end{array}$ & 136 & 3.1 & 3.0 & 3 & 1.03 \\
\hline
\end{tabular}

Table 3: Spearman's rank correlation coefficient - reporting (activities) and characteristics of companies

\begin{tabular}{|l|c|c|c|c|c|c|}
\hline $\begin{array}{l}\text { Reporting - } \\
\text { Activities }\end{array}$ & Revenues & Profit & $\begin{array}{c}\text { Operational } \\
\text { growth }\end{array}$ & $\begin{array}{c}\text { Number of } \\
\text { employees }\end{array}$ & Productivity & Economy \\
\hline $\mathrm{r}$ & $0.284^{* *}$ & $0.392^{* *}$ & $0.240^{* *}$ & $0.186^{*}$ & 0.159 & $0.284 * *$ \\
\hline $\mathrm{p}$ & 0.001 & 0.000 & 0.007 & 0.032 & 0.080 & 0.002 \\
\hline $\mathrm{N}$ & 123 & 114 & 124 & 134 & 122 & 113 \\
\hline
\end{tabular}

Legend: $r$-correlation coefficient; $p$ - level of importance, $N$-number of participants

responsibility for some apparently already well established forms of reporting, whereas a statistically below average for other forms of reporting, also bound to various forms of communication with the public and the employees - shown in Table 5.
With regard to the Spearman's rank correlation coefficient of the reporting on social responsibility, we assessed the connection with regard to the characteristics of companies - the field of activity $(\mathrm{p}=0.028)$, the revenues of the company $(p=0.000)$, profit $(p=0.000)$, number of employ- 
Table 4: Descriptive statistics - reporting in the form of reports

\begin{tabular}{|c|c|c|c|c|c|}
\hline REPORTING in the form of reports & $\mathbf{N}$ & $\mathbf{M}$ & Me & Mo & $\begin{array}{l}\text { St. } \\
\text { Dev. }\end{array}$ \\
\hline $\begin{array}{l}7 \mathrm{a}-\text { In the annual report, we present all the activities of social responsibility } \\
\text { and sustainable development. }\end{array}$ & 136 & 3.9 & 4.0 & 4 & 1.033 \\
\hline $\begin{array}{l}\text { 7e - Via the internal newsletter or other means of internal communication, the } \\
\text { management regularly informs the employees about the key aspects of the com- } \\
\text { pany's social responsibility. }\end{array}$ & 136 & 3.6 & 4.0 & 3 & 1.079 \\
\hline $7 \mathrm{~b}-$ Socially responsible activities are presented on the company's website. & 136 & 3.5 & 4.0 & 3 & 1.192 \\
\hline $\begin{array}{l}7 \mathrm{~g}-\text { The results of socially responsible conduct are presented at various meet- } \\
\text { ings with customers, suppliers, and the local community. }\end{array}$ & 136 & 3.2 & 3.0 & 3 & 0.971 \\
\hline $\begin{array}{l}7 \mathrm{f} \text { - Socially responsible conduct is presented at forums, conferences, and pro- } \\
\text { fessional symposia. }\end{array}$ & 136 & 3.0 & 3.0 & 3 & 1.180 \\
\hline $\begin{array}{l}7 \mathrm{~d}-\text { Socially responsible conduct is presented several times a year at press } \\
\text { conferences and media briefings. }\end{array}$ & 136 & 2.9 & 3.0 & 3 & 1.137 \\
\hline $\begin{array}{l}\text { 7c - We actively participate in bidirectional online communication (blogs, } \\
\text { social networks, such as Facebook, Twitter, etc.). }\end{array}$ & 136 & 2.7 & 3.0 & 2 & 1.215 \\
\hline
\end{tabular}

Table 5: One-way t test - reporting in the form of reports

\begin{tabular}{|l|c|c|c|c|c|c|}
\hline & \multicolumn{7}{|c|}{ Test Value = 3 } & \multicolumn{2}{c|}{ 95\% Confidence Interval of the Difference } \\
\hline & \multicolumn{7}{|c|}{$\mathbf{t}$} & df & $\begin{array}{c}\text { Sig. } \\
\text { (2-tailed) }\end{array}$ & $\begin{array}{c}\text { Mean } \\
\text { Difference }\end{array}$ & Lower & Upper \\
\hline reporting_7a & 9.959 & 135 & 0.000 & 0.882 & 0.71 & 1.06 \\
\hline reporting_7b & 5.251 & 135 & 0.000 & 0.537 & 0.33 & 0.74 \\
\hline reporting_7c & -2.681 & 135 & 0.008 & -0.279 & -0.49 & -0.07 \\
\hline reporting_7d & -1.056 & 135 & 0.293 & -0.103 & -0.30 & 0.09 \\
\hline reporting_7e & 6.996 & 135 & 0.000 & 0.647 & 0.46 & 0.83 \\
\hline reporting_7f & 0.000 & 135 & 1.000 & 0.000 & -0.20 & 0.20 \\
\hline reporting_7g & 2.648 & 135 & 0.009 & 0.221 & 0.06 & 0.39 \\
\hline
\end{tabular}

Table 6: Spearman's rank correlation coefficient - reporting in the form of reports and company's characteristics

\begin{tabular}{|l|c|c|c|c|c|c|c|c|}
\hline $\begin{array}{l}\text { REPORTING - } \\
\text { REPORTS }\end{array}$ & $\begin{array}{c}\text { Field of } \\
\text { activity }\end{array}$ & Ownership & Revenues & Profit & $\begin{array}{c}\text { Operational } \\
\text { growth }\end{array}$ & $\begin{array}{c}\text { No. of } \\
\text { employees }\end{array}$ & Productivity & Economy \\
\hline r & $-0.189 *$ & -0.049 & $0.486^{* *}$ & $0.329 * *$ & 0.119 & $0.346^{* *}$ & $0.228^{*}$ & 0.163 \\
\hline $\mathrm{p}$ & 0.028 & 0.576 & 0.000 & 0.000 & 0.189 & 0.000 & 0.012 & 0.085 \\
\hline $\mathrm{N}$ & 135 & 135 & 123 & 114 & 124 & 134 & 122 & 113 \\
\hline
\end{tabular}

Legend: $r$-correlation coefficient; $p$ - level of importance, $N$ - number of participants

ees $(p=0.000)$, and its productivity $(p=0.012)-$ shown in Table 6.

With the Kruskal-Wallis test, we assessed the reporting on social responsibility with regard to the ownership of organizations participating in our research - shown in Table 7.
With the Spearman's rank correlation coefficient, we evaluated Hypothesis H1, thus examining if more successful companies are more eager to report on social responsibility by means of activities or reports, which is shown in Table 8 . 
Table 7: Kruskal-Wallis test - ranks, reporting by means of reports with regard to the ownership

\begin{tabular}{|l|l|c|c|c|}
\hline & Ownership & N & Mean Rank & M \\
\hline \multirow{3}{*}{$\begin{array}{l}\text { REPORTING }- \\
\text { REPORTS }\end{array}$} & mixed & 11 & 92.23 & 3.81 \\
\cline { 2 - 5 } & foreign (> 50\%) & 12 & 81.08 & 3.52 \\
\cline { 2 - 5 } & domestic state owned (> 50\%) & 44 & 79.25 & 3.50 \\
\cline { 2 - 5 } & public institution & 6 & 62.83 & 3.07 \\
\cline { 2 - 5 } & domestic private (> 50\%) & 135 & 53.69 & 2.96 \\
\cline { 2 - 5 } & Total & & 3.26 \\
\hline
\end{tabular}

Table 8: Spearman's rank correlation coefficient - operational success and reporting

\begin{tabular}{|l|c|c|c|c|c|c|}
\hline & & Productivity & Economy & Revenues & Profit_loss & Operational growth \\
\hline \multirow{2}{*}{ REPORTING_ACTIVITIES } & $\mathrm{r}$ & 0.159 & $0.284^{* *}$ & $0.284^{* *}$ & $0.392^{* *}$ & $0.240^{* *}$ \\
\cline { 2 - 7 } & $\mathrm{p}$ & 0.080 & 0.002 & 0.001 & 0.000 & 0.007 \\
\cline { 2 - 7 } & $\mathrm{N}$ & 122 & 113 & 123 & 114 & 124 \\
\hline $\begin{array}{l}\text { REPORTING_ } \\
\text { REPORTS }\end{array}$ & $\mathrm{r}$ & $0.228^{*}$ & 0.163 & $0.486^{* *}$ & $0.329^{* *}$ & 0.119 \\
\hline
\end{tabular}

Legend: $r$-correlation coefficient; $p$ - level of importance, $N$ - number of participants

\section{Discussion}

The aim of the research was to obtain new aspects, knowledge, and information about the meaning and impact of the connection between internal and external viewpoints on socially responsible conduct and reporting on the success of the operations of large market services organizations. The most crucial are the results of the correlations between socially responsible conduct, socially responsible reporting, and economic success, which is the foundation of an organization's sustainable development.

The research verified the presumption that the representatives of top management in organizations gave highest scores (with regard to the reporting on socially responsible conduct) to the field of environmental protection, especially to the promotion of waste sorting, electricity and heating energy efficiency, as well as water conservation. When it comes to socially responsible activities, there is also a lot of emphasis on occupational health and safety for employees, promotion of team work, as well as continuous improvement of work processes, which are aimed at improving operational results. Activities aimed at socially responsible conduct have been confirmed to be directly connected with the characteristics of companies, especially the revenue $(\mathrm{p}=0.001)$, the profit of a company $(p=0.000)$, operational growth $(p=0.007)$ and operational economy $(\mathrm{p}=0.002)$, and are typical for organizations with a larger number of employees $(p=0.032)$. With regard to the current business environment, the real estate and construction market activities received the lowest scores, which serves as an additional evidence of the expressive economic crisis in the current social environment.
When executing social responsibility in the form of reporting, annual reports for reporting to the public outside the company and presenting the operational results via a website have established themselves as the most common practices, whereas reporting to employees rather takes place as an internal newsletter or other forms of communication. Communicating via social networks or presenting results at traditional conferences, forums, or meetings for partners and the media have established themselves to a much lesser extent. With regard to the ownership of an organization, reporting on socially responsible conduct has been acknowledged very well in case of mixed ownership or if majority owners are foreigners. The score is much lower in case of domestic private ownership or public institutions.

Results from our research are mostly in line with the findings from other studies, especially those that included organizations from Slovenia (KPMG, 2005; KPMG, 2008). The results state that the management in numerous organizations still understands the role and weight of socially responsible conduct when reporting to their social environment, but in practice it is still not evident enough in the implementation of systematic work process improvement (and thus the improvement of operational results). The results are also accordant with the statement that only the business excellence of organizations and their socially responsible conduct can be in favour of the society, and can be the foundation of a long-term development and growth of us all (Mulej and Hrast, 2012).

The results of the research have also demonstrated that companies with significant revenues, high profits, strong operational growth, and with an economical operation to a large extent report on socially responsible activities with the help of the activities in which their employees take part. Companies 
with high revenues, high profits, and an even more significant productivity to a large extent report by means of reports.

We can therefore confirm the Hypothesis $\mathrm{H} 1$ made in the research; systematic reporting on their socially responsible conduct by means of activities and reports is characteristic for companies with high revenues and profits. The research was also based on the presumptions (a) that the portfolio of the stated scientific and expert literature from the fields of quality management, excellence models, and social responsibility standards is extensive enough to allow for a suitably comprehensive approach to the described study method; (b) that the formation of social responsibility factors has to include a growing number of requirements regarding environmental protection, and protection of the rights of consumers and employees, also because of the impact of the most recent global changes in business environments; (c) that especially large and medium sized organizations have a significantly stronger influence on the implementation of the factors of socially responsible conduct; and (d) that senior executives in the organizations possess more extensive knowledge and assume a bigger responsibility in understanding and respecting social responsibility factors. We have also identified some limitations stipulating that only large and medium sized organizations from the field of market services in Slovenia (which otherwise have a predominant influence on the social development) could be included in the research, and that usually only more successful organizations that at the same time assume a higher level of social responsibility can partake in the response to the research. We invited senior executives, who are usually better acquainted with the approaches and principles of social responsibility (as well as understand them better), and assume personal responsibility for the operational results of the organization, to participate in the research. The results of our research can be a good starting point for further studies of the importance of the aspects of social responsibility reporting for operational success, codependency, and the sustainable growth of an organization.

\section{References}

Amabile, T. M. \& Kramer, J. S. (2007). Inner work life. Understanding the subtext of business. Harvard Business Review, 12 (5), 72-83.

Avolio, B.J. \& Gardner, W.L. (2005). Authentic leadership development: Getting to the root of positive forms of leadership. The Leadership Quarterly, 16(3), 315-338, http://dx.doi. org/10.1016\%2Fj.leaqua.2005.03.001.

Bakker, M. (2008). Why CSR reporting in broken - and how it should be fixed, available at: http://www.ethicalcorp.com/ communications-reporting/ethics-and-financial-performance-big-question-\%E2\%80\%93-there-really-business-case $\left(17^{\text {th }}\right.$ february 2013).

Becker, J., Kugeler, M. \& Rosemann, M. (2003). Process Management. Berlin: Heidelberg Springer.

Bodlaj, M. (2009). Povezanost med tržno naravnanostjo, inovacijami in uspešnostjo podjetja - konceptualni model in empirična preverba [Link Between the Market Focus, Innovations and Operational Success - Conceptual Model and Empirical Examination], $\mathrm{PhD}$ thesis. University of Ljubljana, Faculty of Economics
Bukovec, B. \& Markič, M. (2008). The level of integration of various models for organizational change management in Slovenian organizations. International of Journal Business and Systems Research, 2(4), 431-446, http://dx.doi.org/10.1504/ IJBSR.2008.020768

Celinšek, D. \& Markič, M. (2008). Implementing problem - based learning in a highen education institution. International Journal of Management in Education, 2(1), 88-106, http://dx.doi.org/1 $0.1504 \%$ 2FIJMIE.2008.016233.

CSR (2009). Survey on Reporting on Corporate Social Responsibility by the Largest Listed Companies in 11 Central and Easten European Countries. Available at: http://vma.esec.vu.lt/ vma/pluginfile.php/61029/mod_resource/content/0/PFS_ Program-Survey_of_Reporting_on_CSR_in_CEE_BRIC_ and_Ukrane-Septe.pdf (17. 2. 2013).

Daft, R. L. (2010). New era of management. Mason: South-Western: Cengage Learning.

Dimovski, V., Grah, B., Penger, S. \& Peterlin, J. (2010). Authentic Leadership in Contemporary Slovenian Business Environment: Explanatory Case Study of HERMES SoftLab. Organizacija, 43(5), 214-223, http://dx.doi.org/10.2478/ v10051-010-0021-2

Easterby-Smith, M., Thorpe, R. \& Jackson, D. R. (2008) Management Research. London: SAGE Publications, third editions, ISBN 978-1-84787-176-3.

Eurostat (2012). Employment by sex, age and economic, activity (from 2008, NACE rev.2) (1 000). Available at: http://epp. eurostat.ec.europa.eu/portal/page/portal/statistics/search_ database?_piref458_1209540_458_211810_211810.node_ code $=$ lfsa_egan2 $\left(10^{\text {th }}\right.$ August 2012).

Fink Babič, S. \& Biloslavo, R. (2012). Trajnostno poročanje podjetij: priložnosti in izzivi [Sustainable Reporting by Companies: Opportunities and Challenges]. Organizacija, 45(1), 14-26.

Gray, R. \& Milne, M. (2004). Towards Reporting on the Triple Bottom Line: Mirages, Methods and Myths. In: A. Henriques \& J.Richardson. The Tiple bottom line: does it all add up?, 70-80. London, Earthscan.

Green paper (2010). Promoting an European Framework for Corporate Social Responsability. Brussels: European Commission.

Hron, J. (2004). New economy and manager behaviour changes. Agric. Econ. - Czech, 50(1): 9-129. Available at: http://www. cazv.cz/attachments/2-Hron.pdf (4th April 2012).

ISO 26000 (2010). Guidance on Social Responsibility. ISO - the International Organization for Standardization. Available at: http://www.iso.org/iso/home/standards/iso26000.htm (17 h February 2013).

Jeston, J. \& Nelis, J. (2008). Management by Process. Linacre House. Oxford: Jordan Hill, 248-253, http://dx.doi. org/10.1016\%2FB978-0-7506-8761-4.00010-X

Kaplan, R. \& Norton, D. (2006). How to implement a new strategy without disrupting your organization. Harvard Business Review, 84 (3), 100-109.

Kern Pipan, K. (2010). Povzetek temeljnih izsledkov raziskave o uporabi orodij za stalne izboljšave za dvig kakovosti in odličnosti v velikih podjetjih $v$ Sloveniji [Summary of the Key Findings of the Research on the Usage of Tools for Constant Improvements with the Focus on Quality and Excellence Improvements in Slovenian Companies]. Ljubljana: Ministry of Higher Education, Science and Technology, Metrology Institute of the Republic of Slovenia.

Kottler, P. \& Lee, N. (2004). Corporate Social Responsibility: Doing the Most Good for Your Company and Your Cause. Hoboken: John Wiley\&Sons, Inc.

KPMG (2005). International Survey of Corporate Responsibility Reporting. Available at: http://www.kpmg.com.au/Portals/0/ Kpmg\%20Survey\%202005_3.pdf (21 ${ }^{\text {st }}$ June 2012). 
KPMG (2008). International Survey of Corporate Responsibility Reporting. Available at:http://www.kpmg.com/cn/en/issuesandinsights/articlespublications/pages/corporate-responsibility-survey-200810-o.aspx (17 ${ }^{\text {th }}$ February 2013).

KPMG (2011). International Survey of Corporate Responsibility Reporting. Available at: http://www.kpmg.com/PT/pt/ IssuesAndInsights/Documents/corporate-responsibility2011. pdf (17 $7^{\text {th }}$ February 2013).

Margolis, J. D. \& Elfenbein, H. A. (2008). Do Well by Doing Good? Don't Count on it. Harvard Business Review, 86(1), 19-20.

Markič, M., Meško, M., Meško Štok, Z. \& Markič Hrast, S. (2012). Influence of different components of organizational support for project management on success of the project realization in institutes of public health. African Journal of Business Management, 6(9), 3156-3163, http://dx.doi.org/10.5897/AJBM11.272

McAlister, D. T., Ferrell, O. C. in Ferrell, L. (2005). Business and Society: A strategic approuch to social responsbility. New York: Houghton Mifflin Company.

Mulej, M. and Hrast, A. (2012). (Nad-)državna strategija družbene odgovornosti zoper globalno revščino sredi izobilja, Eseji o družbeni odgovornosti, knjiga na zgoščenki [(Supra)national Strategy of Social Responsibility against Global Poverty amidst Abundance, Essays on Social Responsibility, CD Book]. Editor: Matjaž Mulej, Anita Hrast, IRDO - Institute for the Development of Social Responsibility. ISBN 978-961-92971-0-0.

Nohria, N., Groysberg, B. \& Lee, L. (2008). Emploxee motivation: a powerful new model. Harvard Business Review, 86(7-8), 78-84.

Ortenblad, A. (2004). The Learning Organization: Towards an Integrated Model. The Learning Organization, 11(2/3), 129130.

Porter, E., Kramer, M \& Mark, R. (2006). Strategy and Society: Harvard Business Review, (12), 78-92. Available at: http:// www.compromisoempresarial.com/wp-content/uploads/strategy-society.pdf (17 ${ }^{\text {th }}$ February 2013).

Schwarz, S. M. \& Carroll, A. B. (2003). Corporate social responsibility: A three domain approach. Business Ethics Quarterly, 13, 503-530. http://dx.doi.org/10.5840/beq200313435

SFBE (2011). Excellence One Toolbook for Corporate Social Responsibility, Slovenian Foundation for Business Excellence, Available at: http://www.sfpo.org/public/enovice/arhiv _ novic/E-novice_2011_5_mar.pdf $\left(4^{\mathrm{th}}\right.$ April 2012)

Verle, K., Markič, M. \& Kodrič, B. (2012). Kompetence slovenskih managerjev in organizacijska struktura [Competences of Slovenian Managers and Organizational Structure]. Organizacija, 45(1), 2-13.

Wilson, F. M. (2010). Organizatonal Behaviour and Work. New York: Oxford Univesity Press.

Windsor, D. (2006). Corporate Social Responsibility: Three Key Approaches. Journal ob Management Studies, 43(1), 93-114, http://dx.doi.org/10.1111/j.1467-6486.2006.00584.x

Yukl, G. (2010). Leadership in Organizations. New Jersey: Pearson Prentice Hall.

Anton Peršič received a degree in engineering after having completed his studies at the Faculty of Mechanical Engineering, University of Ljubljana. Later on, he graduated from Gea College (Ljubljana), receiving the MBA in Business Administration. Currently, he is finalizing his doctoral thesis at the Faculty of Organisation Studies in Novo mesto, in the field of Quality Management. With more than 30 years of experience in metal and engineering industries, as well as in the services sector, he has been working for the Zavarovalnica Triglav, d.d. insurance company as Head of Standardization for more than 15 years. At the same time, he has taken the leadership and membership in several project teams in the field of reorganization and recording of business processes, and has also served as the administrator of the quality management system and the head reviser of the management system in accordance with ISO 9001 and ISO 27001 at SIQ.

Mirko Markič is a Professor of management in the Faculty of Management Koper at the University of Primorska. He received his Master's and Doctor's degrees from the Faculty of Organizational Sciences, University of Maribor. His work includes more than 420 bibliographical items: articles in science and professional journals as well as in proceedings of scientific and professional conferences. He has worked as leader or member in 15 research and entrepreneurs projects. After 12 years of experience in automotive industry, he started his academic career. 